\title{
Stones of oblivion/stones of truth: A semiotic approach to the Valle de los Caídos and the politics of memory in contemporary Spain
}

\section{Miguel Fernandez Belmonte}

\begin{abstract}
Adding to the few existing studies regarding the Valley of the Fallen and its significance and importance in connection to the politics of memory in contemporary Spain, the article summarizes information regarding the construction of the monument, its architecture and its role relating to the ideology of Franco's regime, also considering the recent, heated discussions on the burials and the future of the building complex. The article suggests an original analysis of the monument's iconography in order to flesh out its concrete connection to the architectural and ideological significance of the Valley of the Fallen implied in previous accounts.
\end{abstract}

Keywords

Francoist Spain, Valley of the Fallen, Semiotics of Commemoration, Political Iconography

\section{Introduction}

On the $1^{\text {st }}$ of April 1959 Franco inaugurated the Valley of the Fallen (Valle de los Caídos) and walked into its basilica under palium together with his wife Carmen Polo. Forty years later an artist painted over the tomb of the dictator with red paint, declaring he did this 'for the freedom and the reconciliation of all the Spanish people'. ${ }^{1}$ These two acts reflect the changes in the perception of a monument in which architectural, artistic and symbolic aspects are intertwined with the histories of the workers and the people buried in the place as well as with the history and politics of memory in contemporary Spain. The complexity of the monument's history is reflected in the interpretation of its meaning that has undergone several changes.

Semiotics can contribute to the analysis of the monument not as a static assertion but as a dynamic system in which the material aspects, the cultural, social and political aspects, 
the monument's creators and the successive generations of users have contributed actively in shaping its meaning (Bellentani and Panico 2016). In doing so, we could understand and describe in a more integrated way, not the meaning that should be definitively attributed to the monument but, as Barthes put it, 'the logic according to which meanings are engendered' (Barthes 1966). We will consider a series of interconnected elements regarding the monument: the significance of the monument in the aftermath of the Spanish Civil War, the significance of the monument as expressed in several related decrees and Franco's discourses, the formal characteristics of the monument in connection to their symbolic values, the significance of the monument for the following generations. ${ }^{2}$

\section{Religion and politics of power}

On the $30^{\text {th }}$ of September, the bishop of Salamanca described the civil war as a Crusade for defending religion, the country and its culture (Fusi 2001). The Spanish Catholic Church showed its unlimited support to Franco through a collective letter by the majority of bishops (only two abstained from signing), and through the distinction of Knight of the Order of Christ, offered to Franco by Pope John XIII. It was as late as 1971 that the Episcopal Assembly decided the Church should issue an apology for her non-reconciliatory role during the civil war.

Throughout Spain, monuments and plaques were built; names were given to roads that praised Franco, Primo de Rivera, founder of the Falange, and the nationalists who died during the civil war. This process was carried out in parallel with the consolidation as hegemonic narrative of a national-Catholic political rhetoric with an emphasis on sacrifice, heroism and martyrdom, in which the victims of God and Spain played a central role (Ferrandiz 2011).

The idea of a great reference monument rose in the rhetorical-ideological context of the Crusade for Spain and of the need to honor the memory of the dead nationalists. ${ }^{3}$ The idea of the Crusade and the exaltation of the victory in the Spanish Civil War of the nationalists were central elements for the creation of the Valley of the Fallen. The monument constitutes an expression of the hegemonic narrative promoted by the forces in power at the time. The martyrs of God and Spain were those who managed to prevail over the dark forces that menaced the country and thus had to be remembered.

The Catholic religion was one of the ideological pillars of the Regime and in the monument the religious faith is indissolubly connected with the politics of power. The first time Franco spoke publicly about the Valley of the Fallen was on June 3, 1939, 'Our monument to the Victory will not be another monument ... it will be a place that will have a church that will have a monastery and barracks ...' (Lafuente 2002). In the Decree of April 1, 1940, which inaugurated the construction works, he stated that 'it is necessary for the stones that will be built to have the magnificence of the ancient monuments, to resist time and oblivion, and 
to become a place of meditation and tranquility in which the future generations will admire those who inherited them a better Spain'. (Decreto de Presidencia de Gobierno, 1 April 1940). The monument is defined in the same decree as 'an eternal place of pilgrimage in which the greatness of nature gives a dignified background to the field where the heroes and martyrs of the Crusade reside'.

On August 23, 1957, the Foundation of the Sacred Cross of the Valley of the Dead was founded with a decree in which the monument was described as a place of prayer and research, as required by 'the religious belief in our Lady, the deep catholic meaning of the Crusade and the social orientation of the new state born after the Victory'. The decree also mentions that the monument regards all the fallen of the war in an attempt to redefine it as a place of reconciliation.

The guide of 1959 from Patrimonio Nacional (public agency responsible for state goods from the Spanish kingdom), refers that 'The Monument to the Fallen for Spain, an idea conceived during the Crusade, must be appreciated by all the Spanish as a token of memory to those who, in defending such a pure ideal, offered unselfishly the greatest and richest property of man: Life'. (Patrimonio Nacional, Guía turística de Sta. Cruz del Valle de los Caídos, BarceIona, 1959, 6-7). At the inauguration on April 1 1959, the day that commemorate Franco's victory in the civil war, the dictator remarked: 'Our war, obviously, was not a civil conflict, but a true Crusade [...] Our country had never before witnessed such great examples of heroism and holiness in so little time'. ${ }^{4}$

\section{Formal characteristics and symbolic value}

The Monument is located in Cuelgamuros, overlooking the mountains of Guadarrama and very close to El Escorial. El Escorial, a monastery, palace, library and pantheon of the Spanish kings, is a building complex linked to the rule of the Spanish Empire of Philip the Second, a great defender and supporter of the Anti-Reformation. It was therefore an important part of the glorious past with which the dictatorship sought to be perceived as its natural successor in the defense of Spain and the universal faith (Bonet Correa 1981).

This ideal relates to the choice of the place for the Valley of the Fallen and its magnificent scale with a large square of thirty thousand six hundred square meters, a gigantic church of two hundred and seventy meters long, dug in the rock with a maximum height of twenty-two meters, crypts, a huge cross, the Benedictine monastery and the access road.

The original design was the work of architect Pedro Muguruza, but when he died in 1950, Diego Mendez took over and made several changes, such as at the height of the church that was doubled. Méndez named the monument in the 1959 guide as 'pre-determined to glorify the memory of those who died for their Homeland'. The works of the Valley of the Fallen, 
whose architecture and artistic features were alien to the ongoing artistic and architectural renewal in Spain, were characterized by their eclecticism and their monumental scale.

The cross, reaching 150 meters high, was one of the most demanding elements of the project. In spite of a competition with twenty drafts in 1950, the commission was offered by Franco directly to Méndez. The architect described the difficulty of the architectural construction of the cross as bigger than that of the Cheops pyramid, and mentioned it was a landmark with which not even recent buildings, such as the Empire State Building, could be compared to (Patrimonio Nacional, 1959). The transition from the base of the cross to the mountain is achieved through a set of huge sculptures by Juan de Ávalos, the main sculptor of the Valley of the Fallen ${ }^{5}$. These are the Evangelists ${ }^{6}$ and above them, the Cardinal Virtues.

Juan de Ávalos reached the maximum to which the sculpture, claiming to represent the orthodoxy of the Regime, could aspire: technical skill, security in sculptural work, figurative expression of loneliness, intimacy and individuality; mastery in rectilinear forms and majesty in the big blocks, characteristics that made Juan de Ávalos the ideal sculptor to work the stone that in the Valley of the Fallen would be destined to commemorate the grandiosity of Franco's life and work and constitutes a palpable sample of the culture imposed by the victors (Bonet Correa 1981).

All the artistic elements of the Valley of the Fallen were not intended for the production of an autonomous aesthetic pleasure but were strongly integrated into a symbolic discourse fed by Christian Catholic iconography and related to a political dimension (as seen in its connection with the values of sacrifice and martyrdom of those who fought for Spain). There are three main architectural elements that determine the symbolic value of the monument besides the importance of the chosen place for its construction and its scale: the square, the cross and the basilica/crypt.

The cross is the affirmation of the Faith, based on the Gospels. The Salvation that the Faith promises can be achieved through the Cardinal Virtues (prudence, fortitude, temperance, justice). Notably, there is no direct representation of the Theological Virtues (faith, hope and charity). The Cardinal Virtues iconography was broadly used in funerary monuments from the $15^{\text {th }}$ century onwards as an allegory associated to the goodness of the deceased, and represented independently from the Vices to which were connected in previous centuries (Olivares Martínez 2017).

In the case of the monument of the Valley of the Fallen there are some elements that follow traditional iconography. The representation of Fortitude treading on a dragon (the triumph of the soul over sin), Temperance holding a bit, Justice holding a sword, Prudence holding a snake all refer to traditional elements of Catholic iconography (Réau 1959) (Luis Monreal y Tejada 2000) (Ordax 2007). Nevertheless, there are variations. The most obvious iconographic 
difference is the fact that the Virtues are represented by male and not by feminine figures, since Franco had estimated that 'women do not usually represent these virtues' (Sueiro 1976).

In the case of the Prudence, the statue holds a stone in his hand instead of the traditional mirror. Justice, who is not blindfolded, holds a tablet in his left hand, instead of a balance or a set of scales, with the round edge alluding to the Tablets of the Law. What seems to be emphasized is the actual application of the Law of God and not the process of divine or worldly judgment.

Above the entrance of the basilica there is an enormous Pieta. The theme of the Pieta belongs to the iconography of the Lamentation of Christ. After the Counter-Reformation, the Virgin offers her Son in sacrifice as a prelude of the institution of the Mass, without the sorrow reflected as in previous representations of the theme in the Middle Ages. After the $17^{\text {th }}$ century the pain of the Virgin becomes a lamentation to God for the sacrifice of the Son (Réau 1957). In the case of the Pieta in the Valley of the Fallen a first version, more in tune with the Counter-Reformation iconography, was dismissed in favor of a version closer to Michelangelo's Pietá. The Virgin holding the dead body of Christ reflects the human sorrow and acts as an intermediary between the divine and the mundane.

Therefore, we may suggest that the conceptual and visual axis of the main view of the Monument is articulated from the mundane level of the believers to the dual nature of Christ embraced by the intermediate figure of the Virgin to the exaltation of the Faith based on the Evangels which Salvation is achieved through the Cardinal Virtues. Symmetrically, the basilica/ crypt is where the believers are conducted from the terrene level to the sacred, approaching the sacred divinity in a linear course of perfection that also finds its spatial parallel in the orientation of the church towards the apse.

In the basilica's interior there are along the nave six chapels dedicated to the Virgin as Patron of the Army and related to different important moments of the History of Spain (Inmaculada Concepción, Nuestra Señora del Carmen, Nuestra Señora de Loreto, Nuestra Señora de África, Nuestra Señora de la Merced, Nuestra Señora del Pilar). ${ }^{7}$ In each chapel there are two sculptures of the Apostles so to be completed the twelve.

When approaching the crossing from the nave there are eight sculptures that represent the fallen during the war (on land, sea and air, plus the volunteers). At the sides of the crossing there are the chapel of the Sepulchre and the chapel of the Most Holy. Is in these chapels and in the ones along the nave that are buried the fallen. At the center of the crossing there is the crucified Christ and around the main altar there are the sculptures of the archangels San Raphael, San Michel, San Gabriel and San Uriel. The last one, according to apocryphal texts ${ }^{8}$, is who at the commandment of God gives soul and spirit to the dead at the day of the judgement. In front of the altar is placed the tomb of José Antonio Primo de Rivera, founder of the Falange and in the opposite side was placed the tomb of Francisco Franco.

We may suggest that, considering the above-mentioned iconographical aspects, the Fallen constitute the paradigm of the Christians that followed the Cardinal Virtues in order to achieve 
Salvation and that with strength and resolution applied the Law of God. They actively fought as soldiers and Christians for Spain and God. The most exemplary Fallen in this scheme will be those nearer to the main altar, that is Primo de Ribera and Franco.

The third main architectural element of the monument is the main square in front of the basilica's entrance, an enormous empty space, the meaning of which becomes activated when addressing the Spanish people, not as single individuals, not as mere observers or visitors, but as a unified crowd (Bonet Correa 1981). This is a crucial element in the overall semiotics of the monument. Only a crowd, where it would not be possible to single out differences which may suggest diversity, can fill the square. The role of the crowd as seen during the inauguration of the monument is intended to be to honor the fallen, to remember their sacrifice and to continue to be alert for the defense of the homeland.

Franco's dictatorial regime failed to translate its ideology into a particular artistic and architectural style. Eclecticism, references to Herrera and Villanueva's architecture, and the absence of clear guides from the Architecture General Directorate headed by Muguruza, were characteristic of the lukewarm and confused architecture of the regime (Bonet Correa 1981). One of the few conscious attempts, and perhaps the only accomplished one, to translate into a specific formal language the ideals that sustained the foundational act of the Regime (the victory at the Spanish Civil War) is the monument of the Valley of the Fallen, with the monumentality of its architecture, its connection to the mountain (forming a solid unity with it) as well as the iconography and scale of its sculptures.

\section{The burials}

Franco and his wife, Carmen Polo, inaugurated the Monument of the Valley of the Fallen on the commemoration day of the victory of the dictator in the civil war. They crossed the church, that had been dug into the rock partly by workers chosen among the defeated in the war, political prisoners who died prematurely due to hard labor (Sueiro 1976), while the national anthem sounded from the organ. Beneath the floor, a few meters apart, in absolute silence, witnessing this ceremony of power and triumph, lay thousands of corpses.

In 1958 the possibility of burial in the Valley of the Fallen was offered without discrimination, on the sole condition that those who will be buried had to be Spanish, Catholic and their relatives would approve their burial (Ferrandiz 2011). According to the official records available by the monastery's Benedictine monks, it is estimated that there are approximately thirty-three thousand eight hundred forty-seven dead bodies in the Valley that were buried there from March 17, 1959 until June 3, 1983 (Ferrandiz 2011). Among them there are also many democrats who were transferred from shared pits without the approval of their relatives, though their exact number cannot be verified. 
On March 31, 1959, the corpse of the founder of the Falange, José Antonio Primo de Rivera, was transferred to the place and on November 23, 1975, Franco, whose tomb was placed in a dominant position next to the altar of the church. Following the general amnesty of 1977 for any incident and crime of political feasibility that took place between July 18, 1936 and December 15, 1976, and with the successor appointed by Franco, King Juan Carlos I, Spain entered in the period know as Transition and with the 1978 constitution were laid the foundations of a democratic regime in the form of a reigning parliamentary democracy.

However, the families of the thousands buried without identification throughout Spain, the defeated of the civil war, waited for justice and claimed the memory of their relatives through forming associations and voicing their truth. In 2000, the Association for the Restoration of Historical Memory was established and in 2007 the Law of Historical Memory was adopted, and was opposed by the People's Party and the Democratic Left of Catalonia because no measure was included to cancel the trials conducted during Franco's dictatorship.

In addition to war reparations, access to relevant records, the withdrawal of street names, statues and other elements that exalted Franco's status, among other issues, the law established an exhumation protocol, provided the publication of an online national map with the common pits, but determined that the costs of locating common pits, exhumation and identification tasks will be borne by individuals. ${ }^{9}$

The law states that 'It is not the role of the legislator to impose a specific collective memory. But it is the duty of the legislator and a commitment to the law, to compensate the victims, to dedicate and protect, with the highest normal power, the right to personal and family memory as an expression of a full democratic state' (Ley de Memoria Histórica, 2007). Regarding the Valley of the Fallen, the monument is a special case in law since it is excluded from the general framework for exhumations and follows the general regulation of public cemeteries and places of worship.

In the crypts (six in the central temple with three levels of storage and two in the transverse with five levels) many bones were placed in wooden boxes with the names and surnames of the dead, or simply their place of origin. The current state of maintenance adds difficulties to the identification works since many boxes have been broken and bones are mixed and also due to the lack of data and the inaccuracies of the documents with the number of deaths. The question of the comprehensive identification of the corpses remains unsolved.

\section{The different memories}

While the formal aspects of the monument are the expression of a specific ideology connected with the elites in power during Franco's dictatorship, the actual monument gives rise to several different reactions and interpretations regarding its meaning and significance. The 
changes in Spanish society under Franco's regime and during the Spanish Transition led to significant transformations regarding the perception of the Valley of the Fallen. The commemoration of the day of the Victory, indissolubly linked to the Monument, was transformed into the Day of the Army, established definitively in 1977 on a different date (Aguilar Fernández 1996).

In the same year, general amnesty was declared and the Spanish Communist Party was legalized and phrases like the Crusade, the Victory, and Our War ceased to be used by the government to refer to the Spanish Civil War. Instead of collective memory regarding the monument, the right to personal and family memory was recognized in the Law of Historical Memory (2007).

Those who still admire and want to honor Franco place flowers on his tomb (until recently at the monument), as his relatives, members of the Franco Foundation and neo-phalangists, experienced and understood the monument in a diametrically different way than the families who still search for their relatives buried without their consent in the crypt (this absence of consent is extended also to some cases of soldiers who fought for Franco).

The opinions of the workers ${ }^{10}$ that built it also differ regarding their personal experiences as they have been recorded by Sueiro in 1976 and studied later by Moreno Garrido. On the website of the church's monument we read that in the founding documents of the Valley of the Fallen:

[...] the emphasis is directly placed on the religious, social and cultural purposes in the service of the pending work of the agreement and the justice among the Spanish people, and to serve as a memorial and burial dyke for all the victims.

There is an important distinction between the fallen and the victims. The name of the monument uses the term Fallen, connected it to the political ideology of the Victory and the Crusade. The term victim, as seen in the website of the church's monument, has been used in recent times not only to refer to the losers of the war but also to the winners. ${ }^{11}$

The historian Julio Aróstegui, who between 2004 and 2013 directed the Historical Memory Chair at the Complutense University in Madrid, denied that the relationship between memory and history is exclusive and analyzed the generational memories of the civil war. He established three main generational memories: of identification and confrontation (imposed in the postwar period to erase republican memory), of oblivion or reconciliation (of the children of those who lived through the war, overcoming collective trauma and producing the narrative of the Transition), of reparation or restitution (of the grandchildren who recovered the memory of the defeated and of the victims of Francoism) (Viñas and Blanco 2017).

Besides, we have what Garrido defined as 'media memory' that comprehends a series of aspects of the representation of the past in the media and through the media that are interrelated with collective memory. In the specific case of the monument of the Valley of the 
Fallen, she analyzed how the media discourse is articulated by referring to different conceptual frames that exist as cultural pre-configurations: the monument as a place of manipulated memory, as a place of erased memory, as a place of contested memory, as a place of persecution, as a religious place (Garrido 2016).

We could go even further by considering all associations that a viewer could establish before the monument as fundamentally subjective and therefore, and the process of giving meaning as open to endless interpretations (Bal and Bryson 1991). But are they really 'endless' or basically conflicting and dynamic?

The role and personal implication of the dictator in the monument have been well documented (as in Aguilar Fernández 1996 and Sueiro 1976), but it would be difficult to consider that the monument 'belongs' exclusively to Franco. We have to consider as well that the purpose for the construction of the building, the ideals that it expressed, did not only belong to the dictator or to a religious and political elite, but were assumed partly or at least not contested by a considerable part of the Spanish society. When in 2018 the government of Pedro Sánchez announced its intention to carry out the exhumation of Franco from the Valley of the Fallen affluence to the monument increased dramatically. For Fernando Ferrandiz, an expert on the civil war and central investigator of the program for memory policies in modern Spain depending on the Ministry of Science and Innovation, the exhumation, that occurred on October 24, 2019, was necessary in order to begin the 'democratization' of the monument and to abolish the hierarchy of victims which conferred in the monument a leading role to Franco and Primo de Rivera (Ferrandiz 2014). Ferrandiz noted that it is impossible to change the meaning of the monument, a unique example in Europe of exaltation of a dictator on such a scale, and to transform it into a reconciliation monument. He underlined the necessity of a center or museum that will explain to visitors what was Franco's dictatorship and how the monument was constructed (Ferrandiz 2018). At present, the government has refrained from launching such a solution, and the status of the monument remains the same: It is classified as a cemetery.

\section{Conclusions}

The cultural, ideological, artistic, architectural, political and social aspects related to the Monument of the Valley of the Fallen do not convey any unique pattern of intention or singular discourse. Rather than an open work, that assumes the task of giving us an image of discontinuity, being it and not narrating it, as Umberto Eco would put it (Eco 1989), the Monument of the Valley of the Fallen transmitted a specific narrative at a certain time which has been reinterpreted along with broader cultural and political changes.

The visitor, the familiar visitor, the winner, the loser, the victim, the fallen, the worker, the children of the workers, the notion of generation in confrontation with the history of contem- 
porary Spain, constitute some of the different ways to experience the monument but also to construct different narratives regarding its meaning.

This is why it is not possible to define the monument in an unequivocal sense. Is it a public cemetery? Is it only a dictator's mausoleum? Is it the assertation of the foundational ideology of the Franco's regime? Could it be a monument for the reconciliation? Is it a religious monument? Is it a regressive attempt to recall the past glory of Spain in its dialogue with the near Monastery-Palace-Kings' Burial of El Escorial? Is it a place to be forgotten so as to 'bury' the profound wounds opened in Spanish society by civil war? Is it a place of remembrance of the injustices and crimes committed during the civil war? Is it a touristic attraction?

The Monument of the Fallen could be approached as the sum of all the perceptions of its significance that are still being confronted in contemporary Spain. Efforts to impose certain narratives upon its specific architectural and artistic form still exist and coexist. Architecture and art produce and define meaning from their conception to their multiple interactions with the cultural subjects. We could therefore approach the monument of the Valley of the Fallen mainly as an attempt to transmit, through specific architectural and artistic forms, the values defended and promoted by the ideology of Franco's regime. In this political context, we believe the specific iconographical aspects of the exterior of the monument and of the basilica's interior call for further study.

\section{NOTES}

1 Juan Diego Quesada: 'Un artista pinta una paloma en la tumba de Franco...'. El País, 31-102018.

2 Its contents were presented partly at the symposium Political monuments of the $20^{\text {th }}$ and $21^{\text {st }}$ century: Memory, Form, Meaning, hold in Thessaloniki 30 ${ }^{\text {th }}$ November- $1^{\text {st }}$ December 2018, organized by the Association of Greek Art Historians in collaboration with the Interuniversity Postgraduate Programme in Museology.

3 A precedent existed in the project of Luis Moya of 1937 published in September 1940 in the magazine Vértice 'Sueño arquitectonico para una exaltación nacional' (Architectural Dream for a National Elevation) in: Bonet Correa, A. (coord.) 181. Arte del franquismo.

4 A summary of the references to the Valley on the Fallen in related decrees can be found in Aguilar Fernández, P. 1996. Memoria y olvido de la Guerra Civil española. Madrid: Alianza and in Moreno Garrido, B. 2010. El Valle de lo Caídos: una nueva aproximación. Revista de Historia Actual. Vol.8.

5 There were also other sculptors and artists who worked on the various works in the church such as Carlos Ferreira, Luis Antonio Sanguino, Antonio Marin, Ramón Mateu, Ramón Lapayese, Beovide. 
6 Franco rejected a Saint John with a beard and Ávalos did it again, and Franco had rejected the original sculpture of Pieta over the entrance of the church (Sueiro 1976).

7 Detailed information regarding the interior of the Basilica can be found at the Abadía de la Santa Cruz of the Valley of the Fallen webpage

http://www.valledeloscaidos.es/monumento/paso

8 'The Apocalypse of Peter' In The Apocryphal New Testament. Translation and notes by M.R. James 1924. Oxford: Clarendon Press.

9 The exhumations regard the democrats because, starting in 1942, the Franco government was able to identify and bury the deaths of the national army.

$10 \mathrm{It}$ is not possible to know exactly how many prisoners and workers have worked in the works. Isaías Lafuente calculates an average of 400 to 500 men while Raymond Carr and Juan Carlos Fusi give a total of 20,000 men.

11 This approach can be related to recent publications, as those of Stanley G. Payne, that assume an 'objective' distance far from biased points of view and considers that the left forces had more responsibility in the beginning of the civil war (Viñas and Blanco 2017).

\section{REFERENCES}

España de la posguerra. La Actualidad Española, 2 in: Sueiro, D. 1976. La verdadera historia del valle de los caídos. Madrid: Sedmay.

Aguilar Fernández, P. 1996. Memoria y olvido de la Guerra Civil Española. Madrid: Alianza.

Bal, M. and Bryson, N. 1991. Semiotics and Art History. In: The Art Bulletin, 73(2): 174-208.

Barthes, R. 1966. Critique et verité. Paris: Editions du Seuil.

Bellentani, F. and Panico, M. 2016. The meanings of monuments and memorials: toward a semiotic approach. Punctum 2(1): 28-46.

Bonet Correa, A. 1981. Arte del franquismo. Madrid: Cátedra.

Eco, U. 1989 [1962]. The open work. Michigan: Harvard University Press.

Ferrándiz, F. 2014. El pasado bajo tierra. Exhumaciones contemporáneas de la Guerra Civil. Barcelona: Anthropos.

Ferrandiz, F. 22-08-2018. Interview on la Sexta Channel.

Ferrandiz, F. 2011. Guerras sin fin: guía para descifrar el Valle de los Caídos en la España contemporánea. Política y Sociedad 48(3): 481-500.

Fusi, J. P. 2001 [1985]. Franco: Autoritarismo y poder personal, Debolsillo.

Lafuente, I. 2002. Esclavos por la patria, La explotación de los presos bajo el franquismo in: Moreno Garrido, B. 2010. El valle de los caídos: una nueva aproximación. RHA 8(8): 31-44. 
Ministerio de Justicia, Exposición de motivos, Ley de Memoria Histórica 52-2007, December 26.

Monreal y Tejada, L. 2000. Iconografía del Cristianismo. Barcelona: El Alcantilado.

Moreno Garrido, B. 2010. El Valle de los Caídos: una nueva aproximación. Revista de Historia Actual. Vol.8.

Moreno Garrido, B. 2016. Medios, imágenes y memoria: el Valle de los Caídos. PhD Thesis. Madrid: Universidad Complutense de Madrid.

Olivares Martínez, D. 2017. Base de datos digital de Iconografía Medieval. Universidad Complutense de Madrid. Available at https://www.ucm.es/bdiconografiamedieval/granada 0509-2019 (accessed 09-09-2019).

Ordax, S. A. 2007. Iconografía de las virtudes a fines de la Edad Media: la fachada de San Pablo de Valladolid. Valladolid: Universidad de Valladolid.

Patrimonio Nacional 1959. Guía turística de Sta. Cruz del Valle de los Caídos. Barcelona.

Réau, L. 1959. Iconographie de L'Art Chrétien. Paris: Presses Universitaries de France.

Sueiro, D. 1976. La verdadera historia del valle de los caídos. Madrid: Sedmay.

Viñas, A. and Blanco, J. A. 2017. La Guerra Civil española, una visión bibliográfica. Madrid: Marcial Pons.

Miguel Fernandez Belmonte is an art historian and museologist who teaches at the University of Thessaly.

Email: info@mfbelmonte.art 